\title{
Occurrence of thermophilic fungal communities and its growth rate on different media and temperatures from available natural substrates
}

\author{
Birajdar G Mํㄹ V R Kumbhar ${ }^{1}$, K S Kadam ${ }^{2} \&$ U N Bhale ${ }^{1^{*}}$ \\ ${ }^{1}$ Research Laboratory, Department of Botany, Arts, Science and Commerce College, Naldurg, Osmanabad 413 602, Maharashtra, India \\ ${ }^{2}$ Department of Botany, K.K.M. College, Manwat, Parbhani 431 505, Maharashtra, India \\ * Email: unbhale2007@rediffmail.com
}

\section{ARTICLE HISTORY}

Received: 31 December 2019

Accepted: 13 February 2020

Published: 01 April 2020

\section{KEYWORDS}

Organic substrates; Thermophilic fungi; Different media and temperatures; Percentage of incidence

\section{ABSTRACT}

Thermophilic fungi are the chief components of the microflora that develops in heaped masses of plant materials, piles of agricultural and forestry products and other accumulation of organic matter. In this investigation, survey was conducted and collected different compost samples from eight localities of Osmanabad district. Among these localities, Naldurg and Dhoki sites showed highest number of organic substrates, while least in Itkal. Physicochemial properties i.e. nitrogen, phosphorus, potassium, total organic matter, total carbon and moisture were analysed from available composts and among them nitrogen was highest in molasses. Isolation of fungi was made from substrates and among five substrates, vermicompost and Farm Yard Manure (FYM) were recorded for highest species richness and \% incidence while less in molasses. Among isolated thermophilic fungi, Aspergillus niger, A. flavus, Rhizoctonia solani, A. fumigatus and Rhizopus sp. found abundant in all the substrates and temperature ranges. Fungal species A. niger, Mucor mucedo, A. flavus and Pythium sp. Highest growth on all three media viz. Potato dextrose agar (PDA), Czapek's Dox Agar (CZA) and Martins Rose Bengal (MBR) were recorded. A. niger and Rhizopus sp. were found dominant in tested media and temperature. Generally, the fungi show very little growth at $65^{\circ} \mathrm{C}$. Every temperature gradient showed the growth incidence in all substrates but room temperature (RT) and $35^{\circ} \mathrm{C}$ showed richness of fungal incidence. Even some species showed the growth on some substrates at higher temperate $\left(65^{\circ} \mathrm{C}\right)$ to some extent.

\section{Introduction}

The response of fungi to temperature varies between the two extremes of obligatorily thermophilic through thermotolerance to psychrophilic species. However, majority of known fungi are mesophiles developing in culture between 5 and $37^{\circ} \mathrm{C}$; the psychrophiles extend below that range of temperature (1). Thermophilic aerobic micro-organisms are physiologically very active and are capable of producing several thermostable enzymes responsible for decomposition of cellulose and to a great extent lignin into simpler compounds. According to its etymological meaning, composting denotes to a bio degradation process of a mixture of substrates carried out by a microbial community composed of various populations in aerobic conditions and in the solid state. It was described the concepts of compost i.e. organic matter is an important component of soil which includes of plant and animal residues that are made up of complex carbohydrates, starch, cellulose, hemicellulose, lignin, protein, fats, organic acids, oils resins etc. (2) Furthermore, compost has a high nutritional value with high concentrations of especially nitrogen, phosphorus and potassium, while the contamination by heavy metals and other toxic substances are very low (3). Agricultural waste products like- animal dung, manure and crop residues are potential sources of plant nutrients and for the complete decomposition of lignocellulosic wastes which involves cellulases, hemicellulases and lignolytic enzymes. Degradation of composts was carried out by huge mixture of bacteria, fungi, insects, worms and other organisms that eat materials and recycle them into new forms (4). Sustainable agricultural practice was found through organic

(C) Birajdar et al. (2020). This is an open-access article distributed under the terms of the Creative Commons Attribution License, which permits unrestricted use, distribution, and reproduction in any medium, provided the original author and source are credited (https://creativecommons.org/licenses/by/4.0/)

To cite this article: Birajdar GM, Kumbhar VR, Kadam KS, Bhale UN. Occurrence of thermophilic fungal communities and its growth rate on different media and temperatures from available natural substrates. Plant Science Today. 2020;7(2):172-177. https://doi.org/10.14719/pst.2020.7.2.719 
composts which can fulfil the crop productivity and human needs along with conservation of available resources without harming the environment (5). Nutrient and organic matter contents of composts have been studied extensively by previous workers (6-8). Similar results were also reported and isolated fungi from different thermogenic places (9). Therefore, the present work has been made to occurrence of thermophilic fungal communities and its growth rate on different media and temperatures from available natural substrates.

\section{Materials and Methods}

\section{Substrates collections sites}

Study site (Osmanabad district) comes under Marathwada regions of Maharashtra state of India. Five different organic substrates viz. vermicompost, poultry manure, farm yard manure (FYM), cow dung and molasses were collected. Samples were collected from eight different localities i.e. Naldurg, Itkal, Murum, Lohara, Dhoki, VashiParanda and Waghdari.

\section{Analyses of physico chemical parameters}

Different composts were collected from study area and analysed physicochemical characterization. Composts were spread out on a tray for air drying. It was sieved over a $150 \mathrm{~mm}$ sieve and used for characterization. Each sample was weighed using digital balance. The samples were oven-dried at a temperature of $110{ }^{\circ} \mathrm{C}$ for $24 \mathrm{hrs}$ and reweighed. Moisture and Nitrogen content was determined by the Kjeldahl method $(10,11)$. The carbon content of compost was determined by titration method as described (12). Phosphorus was determined by Olsens method by using spectrophotometer (13-15). Water soluble and exchangeable potassium was calculated by Ammonium acetate method (16) using Flame photometer. Samples of each heap of compost collected at 5-7 cm depth level and moisture content was determined.

\section{Isolation and identification of thermophilic fungi}

\section{Dilution plate technique}

The isolation of thermophilic fungi from different substrates was carried out using dilution plate technique $(17,18)$. Ten gms of sample were transferred to a flask containing $100 \mathrm{ml}$ sterile water. The contents were centrifuged with centrifuge machine for $15 \mathrm{~min}$ and then diluted $10^{-3}$ of $0.5 \mathrm{ml}$ was transferred to sterile petri plates containing different media in triplicates. The $\mathrm{pH}$ of medium was adjusted to 6.5 with $0.1 \mathrm{~N} \mathrm{HCl}$ or $0.1 \mathrm{~N} \mathrm{NaOH}$. Petri plates were incubated in an inverted position at room temperature (RT) and adjusted the temperature in hot air oven at 35 to $65^{\circ} \mathrm{C}$. Pure cultures of isolates were maintained on respective media slants at $4{ }^{\circ} \mathrm{C}$ for further study. The percentage of incidence was calculated by employing the following formula (19).

$$
\% \text { Incidence }=\frac{\text { No of colonies of species in all plates }}{\text { Total no of colony of the all the species in all plates }} \times 100
$$

Different types of media viz. Potato dextrose agar (PDA) Czapek's Dox Agar (CZA) and Martins Rose Bengal (MBR) agar media were used for collection and isolation of thermophilic fungi. The different topographical characters of the colonies were recorded at regular time intervals. The semipermanent slides of the isolated fungi were prepared using $1 \%$ cotton blue and lactophenol. Identification of thermophilic fungi was made by referring relevant literature and monographs (20-23). Key to the identification of thermophilic fungi was used according to a published work (24).

\section{Results}

\section{Sample collection}

Organic substrates were collected from different places of Osmanabad district. Study sites shows different types of compost viz. vermicompost, poultry manure, molasses, farm yard manure (FYM), cow dung etc. These samples were collected from different eight localities i.e. Naldurg $\left(17.82^{\circ} \mathrm{N}\right.$ and $\left.76.30^{\circ} \mathrm{E}\right)$, Itkal $\left(17.76^{\circ} \mathrm{N}\right.$ and $\left.76.14^{\circ} \mathrm{E}\right)$, Murum $\left(17.96^{\circ} \mathrm{N}\right.$ and $\left.76.47^{\circ} \mathrm{E}\right)$, Lohara $\left(17.98^{\circ} \mathrm{N}\right.$ and $\left.76.32^{\circ} \mathrm{E}\right)$, Dhoki $\left(18.37^{\circ} \mathrm{N}\right.$ and $\left.76.12^{\circ} \mathrm{E}\right)$, Vashi $\left(18.54^{\circ} \mathrm{N}\right.$ and $\left.75.78^{\circ} \mathrm{E}\right)$ and Paranda $\left(18.46^{\circ} \mathrm{N}\right.$ and $\left.75.65^{\circ} \mathrm{E}\right)$ and Wagdari $\left(17.45^{\circ} \mathrm{N}\right.$ and $\left.76.15^{\circ} \mathrm{E}\right)$. Among these localities, Naldurg and Dhoki site showed highest number of organic substrates while least in Itkal (Table 1).

Table 1. Collection of different types of organic substrate (composts) from different study sites.

\begin{tabular}{ccccccccc}
\hline \multirow{2}{*}{$\begin{array}{c}\text { Sl } \\
\text { No. }\end{array}$} & \multirow{2}{*}{ Place } & \multirow{2}{*}{ NL } & \multirow{2}{*}{ EL } & \multicolumn{5}{c}{ Organic Substrates } \\
\cline { 5 - 9 } & & & PM & VC & FYM & CD & M \\
\hline 1 & Naldurg & $17.82^{\circ}$ & $76.30^{\circ}$ & -- & Yes & - & Yes & Yes \\
\hline 2 & Itkal & $17.76^{\circ}$ & $76.14^{\circ}$ & Yes & -- & -- & Yes & - \\
\hline 3 & Murum & $17.96^{\circ}$ & $76.47^{\circ}$ & -- & -- & -- & Yes & Yes \\
\hline 4 & Lohara & $17.98^{\circ}$ & $76.32^{\circ}$ & -- & -- & -- & Yes & Yes \\
\hline 5 & Dhoki & $18.37^{\circ}$ & $76.12^{\circ}$ & -- & Yes & -- & Yes & Yes \\
\hline 6 & Vashi & $18.54^{\circ}$ & $75.78^{\circ}$ & -- & -- & Yes & Yes & -- \\
\hline 7 & Paranda & $18.46^{\circ}$ & $75.65^{\circ}$ & -- & Yes & Yes & Yes & -- \\
\hline 8 & Wagdari & $17.45^{\circ}$ & $76.15^{\circ}$ & -- & Yes & Yes & Yes & -- \\
\hline
\end{tabular}

NL-North Latitude, EL-East Longitude, VC- Vermicompost, PMPoultry manure, FYM- Farm yard manure, CD-Cow dung

\section{Physicochemical parameters of substrates}

Physicochemical parameters were tested from 5 different sources of available organic substrates such as poultry manure, vermicompost, FYM, cow dung and molasses. Organic fertilizers contain relatively low concentrations of the actual plant nutrients and are not immediately available for plant utilization. Hence, the fortification of organic wastes and their composts as a source of organic nutrients are imperative for sustainable agriculture. Nitrogen content was found highest in molasses (1.12\%) than other compost. The lowest value of nitrogen $(0.78 \%)$ occurs in FYM. In poultry manure, phosphorus and potassium were found very less as compared to other compost while more in VC. Total carbon (\%) range is found in between 25.50 to $35.88 \%$ in tested compost. Moisture (\%) content was found more in cow dung, FYM and molasses while least in poultry manure and VC. Total organic matter (OM) was ranged from 44 to 
Table 2. Physico-chemical parameters of different organic compost.

\begin{tabular}{clrrrrr}
\hline Sl. No. & \multicolumn{1}{c}{ Parameters } & \multicolumn{1}{c}{ Poultry Manure } & \multicolumn{1}{c}{ Vermicompost } & \multicolumn{1}{c}{ FYM } & \multicolumn{1}{c}{ Cow dung } & \multicolumn{1}{c}{ Molasses } \\
\hline 1 & $\mathrm{~N}(\%)$ & $0.84 \pm 04$ & $0.90 \pm 0.21$ & $0.78 \pm 0.12$ & $0.84 \pm 0.22$ & $1.12 \pm 0.12$ \\
\hline 2 & $\mathrm{P}(\%)$ & $0.07 \pm 0.1$ & $0.05 \pm 0.01$ & $0.02 \pm 0.01$ & $0.16 \pm 0.03$ & $0.13 \pm 0.01$ \\
\hline 3 & $\mathrm{~K}(\%)$ & $0.01 \pm 0.001$ & $3.77 \pm 0.97$ & $1.42 \pm 0.33$ & $4.01 \pm 1.01$ & $1.28 \pm 0.19$ \\
\hline 4 & Total Carbon (\%) & $35.09 \pm 2.33$ & $27.15 \pm 4.45$ & $25.50 \pm 6.21$ & $35.88 \pm 2.66$ & $34.23 \pm 6.33$ \\
\hline 5 & Total OM (\%) & $60.50 \pm 3.11$ & $46.85 \pm 5.56$ & $44.00 \pm 4.11$ & $61.87 \pm 2.22$ & $59.05 \pm 9.11$ \\
\hline 6 & Moisture (\%) & $8.70 \pm 2.31$ & $6.95 \pm 2.11$ & $28.39 \pm 5.23$ & $50.99 \pm 7.01$ & $58.97 \pm 7.11$ \\
\hline
\end{tabular}

Each value is the mean of three replicates, Standard error \pm

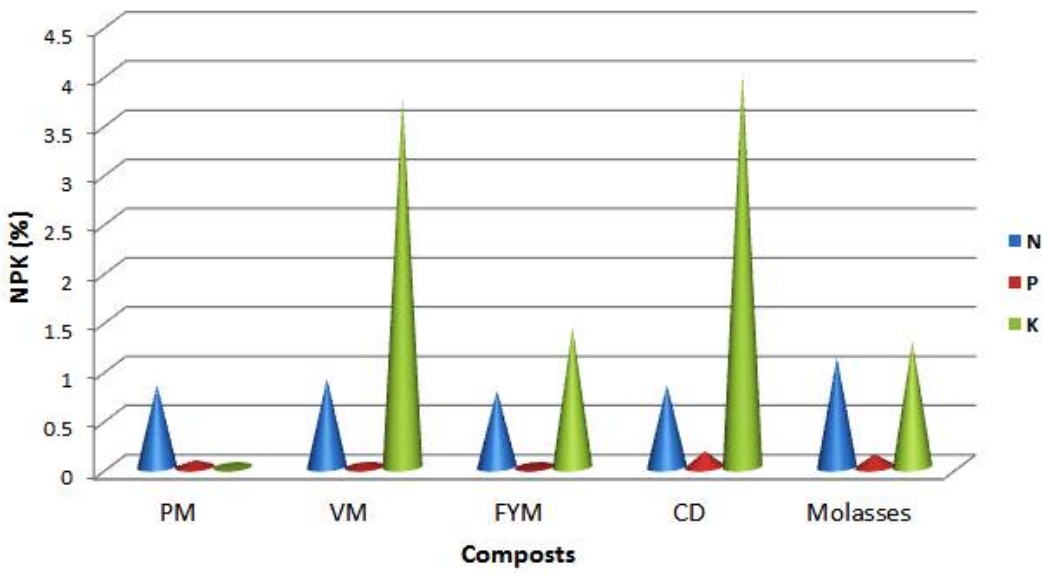

Fig. 1. Percentage of NPK in available composts.

PM-Poultary manure, VM-Vermicompost, FYM-Farm yard manure, CD-Cow dung

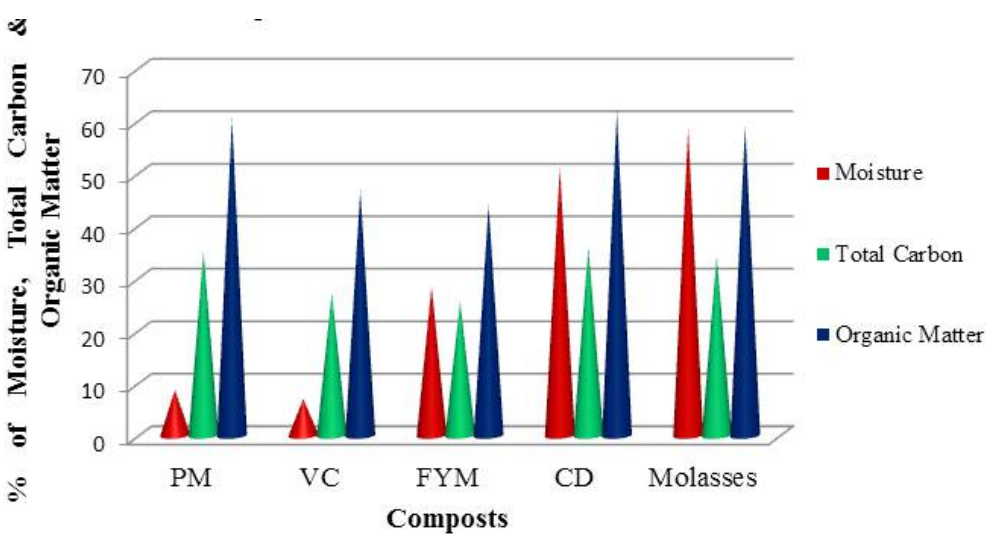

Fig. 2. Percentage of moisture, total carbon \& organic matter in available composts. PM-Poultary manure, VC-Vermicompost, FYM-Farm yard manure, CD-Cow dung.

$60.50 \%$ in all composts, while the lowest value was found in FYM, while highest in poultry manure (Table 2; Fig. 1 \& 2).

\section{Incidence of thermophilic fungal growth on different temperatures and media}

Isolated fungi are grown at different temperatures i.e. RT, 35, 45, $55 \& 65{ }^{\circ} \mathrm{C}$ on the different media. Growth was observed on all temperature gradients and media, except $65{ }^{\circ} \mathrm{C}$ (Table 3). Generally; the fungi show very little growth at $65{ }^{\circ} \mathrm{C}$. The optimum growth of the fungi was observed between RT and 35 ${ }^{\circ} \mathrm{C}$. Twenty five fungal species representing 19 genera were isolated from organic substrates (Table 4). In case of PDA medium, the highest incidence was found at RT and $35^{\circ} \mathrm{C}$. Aspergillus niger and Rhizoctonia sp. (79.3 and 70.6\%) respectively followed by Humicola insolens while lowest incidence occurred in Mucor mucedo, Myceliopthora thermophila and Cladospora thermophila at $65{ }^{\circ} \mathrm{C}$. Martins Rose Bengal (MBR) medium was respond highest incidence of Mucormiehei (65.3\%) at RT while $A$. niger and $C$. thermophila were found lowest incidence. In case of
Czapak Dox Agar (CZA) medium, Aspergillus flavus (72.6\%) at $35^{\circ} \mathrm{C}$ and $A$. niger (69.5\%) at RT was found highest incidence while least in $A$. niger at $65^{\circ} \mathrm{C}$.

\section{Growth rate of thermophilic fungi at higher} temperature

The impacts of temperature on growths rely upon numerous components, including the family, species and strain of the organism, the measure of accessible water, sorts of supplements and numerous other natural elements. Obviously, temperature was likewise a significant factor. In our examination on temperature connections for the parasites has been done at three unique temperatures viz. 45, 55 and 65 ${ }^{\circ} \mathrm{C}$. It was seen that at $45^{\circ} \mathrm{C}$ development rate of $A f$, $A f l, H i, R, M t, P c, C t$ and $C$. thermophilium was maximum while at same temperature development rate of $M m, P P b, A a, F o, G$ was minimum. At the equivalent, $45^{\circ} \mathrm{C}$ development rate of $\mathrm{Hl}, \mathrm{Pd}$ and $\mathrm{Tv}$ was found medium subsequently there was no growth rate on $\mathrm{Ar}, \mathrm{At}, \mathrm{Mmi}, \mathrm{Rs}$, Th and $\mathrm{C}$. At $55{ }^{\circ} \mathrm{C}$ development rate of $A f, H l$ and $P c$ was minimum while $A f l, H i, R, M t, C t$ and $C$. thermophilium was 
Table 3. Thermophilic fungal diversity and growth rate at higher temperature

\begin{tabular}{|c|c|c|c|c|c|c|}
\hline Temp $\longrightarrow$ & & & Higher Temper & $\left({ }^{0} \mathrm{C}\right)$ & & \\
\hline & Growth Rate & 45 & Growth Rate & 55 & Growth Rate & 65 \\
\hline$\nabla$ & & & & & & \\
\hline Aspergillus fumigatus & Maximum & +++ & Minimum & + & No & - \\
\hline Aspergillus niger & Maximum & +++ & Medium & ++ & No & - \\
\hline Aspergillus flavus & Maximum & +++ & No & - & Minimum & + \\
\hline Aspergillus rapens & No & - & No & - & No & - \\
\hline Aspergillus tamari & No & - & No & - & No & - \\
\hline Mucor mucedo & Minimum & + & No & - & No & - \\
\hline Mucor miehei & No & - & No & - & Minimum & + \\
\hline Humicola insolens & Maximum & +++ & Medium & ++ & No & - \\
\hline Humicola lanuginosa & Medium & ++ & Minimum & + & No & - \\
\hline Pythium sp. & Minimum & + & No & - & No & - \\
\hline Rhizotonia solani & No & - & No & - & No & - \\
\hline Rhizoctonia sp. & Maximum & +++ & Medium & ++ & Minimum & - \\
\hline Myceliophthora thermophila & Maximum & +++ & Medium & ++ & No & + \\
\hline Penicillium cinnmoni & Maximum & ++++ & Minimum & + & Minimum & - \\
\hline Penicillium duponti & Medium & ++ & No & - & No & - \\
\hline Penicillium befeldianum & Minimum & + & No & - & No & - \\
\hline Alternaria alternata & Minimum & + & No & - & No & - \\
\hline Fusarium oxysporun & Minimum & + & No & - & No & - \\
\hline Trichoderma viride & Medium & ++ & No & - & No & - \\
\hline Trichoderma harzianum & No & - & No & - & No & - \\
\hline Cladospora thermophila & Maximum & +++ & Medium & ++ & Minimum & + \\
\hline Cladosporum sp. & No & - & No & - & No & - \\
\hline Geotrichum candidum & Minimum & + & No & - & No & - \\
\hline Chaetomium thermophilum & Maximum & +++ & Medium & ++ & Minimum & + \\
\hline Torula sp. & Minimum & + & No & - & No & - \\
\hline
\end{tabular}

medium. It was seen that at $55{ }^{\circ} \mathrm{C}$ there was no development rate of $A n, A r, A t, M m, M m i, P, R s, P d$, $\mathrm{Pb}, \mathrm{Aa}, \mathrm{Fo}, \mathrm{Tv}, \mathrm{Tk}, \mathrm{C}$ and $\mathrm{G}$. At $65^{\circ} \mathrm{C}$ development rate of $A f l, M m i, R, P c, C t$ and $C$. thermophilium was least. Furthermore, at a similar temperature there was no development rate of $A f, A n, A r, A t, M m, H i, H l, R s, M t$, $P d, P b, A a, F o, T v, T h, C$ and $G$ (Table 3).

\section{Discussion}

The present investigation supports earlier findings, as compare to soil compost has relatively low nitrogen content between 0.5 to $2.0 \%$, that is slowly mineralized in soil $(25,26)$. It was reported that the vermicompost had lower $\mathrm{pH}$, total organic carbon (TOC), organic matter (OM) and carbon/nitrogen ratio $(\mathrm{C} / \mathrm{N}$ ratio) but higher electrical conductivity (EC), nitrogen, phosphorous and potassium (NPK) content than the raw substrate and the heavy metal content in vermicompost was higher than that of raw substrates (27). Nitrogen content is found highest in molasses than other compost; these results are in agreement with those obtained and found that the total nitrogen rate ranged from 0.99 to $2.01 \%$ (28). In poultry manure, phosphorus and potassium are found very less as compared to other compost, these results are in agreement with the results obtained and found that the $\mathrm{C} / \mathrm{N}$ ratio ranged from $15: 1$ to $20: 1$ and it was ideal for ready-to-use compost (29). Moisture (\%) content was found more in cow dung; these results are in agreement with the optimum value of total organic matter higher than $10 \%$ (30).
It was reported that, bagasse as a source of thermophilic fungi (31) and the baled or heaped bagasse made development of thermophilic microorganisms (32). The occurrence of Humicola lanaginosus in the manure was also reported (33). It was reported the occurrence of Cheatomium thermophile varcoprophile on goat dung (34). Recently, it was isolated 22 thermophilic fungi belonging to 8 genera on different substrates from different region of Dharwad (Karnataka State) (35). The thermophile $T$. lanuginosus was one of the most common fungi occurring in soil (36). Fungal consortium of Aspergillus and Humicola sp., and actinomycetes, especially Streptomyces had been earlier used for the conversion of nutrient rich compost (37). It was reported that microorganisms isolated and characterized from the above composts include the species of fungi viz., Aspergillus, Trichoderma, Mucor, Penicillium, Alternaria, Cladosporium, Monilia, Helminthosporium, Coccidioides, Scedosporium, actinomycete viz., Nocardia and bacteria viz., Bacillus, Lactobacilli, Micrococcus, Pseudomonas, Clostridium. Of these isolates, members of the genus Aspergillus were most prevalent (38\%) followed by Bacillus comprising of $20 \%$ of the total microbial isolates (38). It was reported that there were seven different types of thermophilic fungi from forest leaf litters and tested on YpSs Emerson agar medium and analyzed the radial growth on variable temperatures $\left(30-55{ }^{\circ} \mathrm{C}\right)$ (39). It was reported that the isolation of 20 species belonging to 7 genera on different substrates collected from different places of Osmanabad district 
Table 4. Percentage of Incidence of thermophilic fungi from different culture media and temperatures.

\begin{tabular}{|c|c|c|c|c|c|c|c|c|c|c|c|c|c|c|c|}
\hline \multirow{3}{*}{$\begin{array}{l}\text { Temp } \\
\left({ }^{\circ} \mathrm{C}\right) \\
\text { Fungi }\end{array}$} & \multicolumn{15}{|c|}{ CULTURE MEDIA } \\
\hline & \multicolumn{5}{|c|}{ PDA } & \multicolumn{5}{|c|}{ MBR } & \multicolumn{5}{|c|}{ CZA } \\
\hline & RT & 35 & 45 & 55 & 65 & RT & 35 & 45 & 55 & 65 & RT & 35 & 45 & 55 & 65 \\
\hline $\boldsymbol{A f}$ & 57.5 & 49.2 & 40.3 & 29.6 & 0 & 48.9 & 50.2 & 0 & 0 & 0 & 31.9 & 19.0 & 16.4 & 0 & 0 \\
\hline An & 79.3 & 39.9 & 21.1 & 0 & 0 & 59.3 & 45.2 & 28.5 & 17.2 & 13.4 & 69.5 & 50.3 & 31.2 & 17.2 & 10.9 \\
\hline$A r$ & 31.6 & 14.9 & 0 & 0 & 0 & 42.1 & 34.8 & 15.6 & 13.0 & 0 & 24.6 & 29.5 & 0 & 0 & 0 \\
\hline$A t$ & 0 & 0 & 0 & 0 & 0 & 21.6 & 15.3 & 0 & 0 & 0 & 0 & 0 & 0 & 0 & 0 \\
\hline$M m$ & 16.5 & 12.0 & 0 & 0 & 0 & 49.5 & 53.8 & 37.5 & 16.5 & 0 & 34.2 & 36.5 & 15.9 & 0 & 0 \\
\hline Mmi & 29.3 & 14.2 & 0 & 0 & 11.5 & 65.3 & 45.5 & 0 & 0 & 0 & 0 & 0 & 0 & 0 & 0 \\
\hline $\mathrm{Hi}$ & 68.9 & 65.5 & 46.8 & 19.8 & 0 & 0 & 42.8 & 19.2 & 0 & 0 & 0 & 0 & 0 & 0 & 0 \\
\hline Hl & 36.4 & 30.2 & 18.5 & 15.2 & 0 & 0 & 24.2 & 20.1 & 0 & 0 & 0 & 0 & 0 & 0 & $\overline{0}$ \\
\hline Rs & 0 & 0 & 0 & 0 & 0 & 14.5 & 0 & 0 & 0 & 0 & 21.6 & 0 & 0 & 0 & $\overline{0}$ \\
\hline$R m$ & 69.5 & 70.6 & 48.6 & 19.5 & 0 & 0 & 0 & 0 & 0 & 0 & 0 & 0 & 0 & 0 & 0 \\
\hline Mt & 52.3 & 50.3 & 35.7 & 24.5 & 14.4 & 51.3 & 48.7 & 24.6 & 16.4 & 0 & 0 & 0 & 0 & 0 & 0 \\
\hline$P c$ & 34.8 & 30.8 & 0 & 20.5 & 0 & 17.3 & 23.7 & 0 & 0 & 0 & 35.1 & 24.8 & 14.7 & 0 & 0 \\
\hline$P d$ & 42.6 & 21.5 & 11.1 & 0 & 0 & 0 & 15.6 & 0 & 0 & 0 & 42.8 & 35.9 & 19.2 & 14.0 & 0 \\
\hline$P b$ & 0 & 0 & 0 & 0 & 0 & 25.8 & 12.5 & 0 & 0 & 0 & 42.7 & 0 & 21.9 & 17.1 & 0 \\
\hline Aa & 0 & 0 & 0 & 0 & 0 & 32.0 & 24.8 & 19.5 & 0 & 0 & 0 & 0 & 0 & 0 & 0 \\
\hline Fo & 0 & 0 & 0 & 0 & 0 & 32.1 & 30.2 & 16.5 & 0 & 0 & 0 & -0 & 0 & 0 & 0 \\
\hline$T v$ & 29.2 & 25.9 & 19.5 & 0 & 0 & 32.4 & 30.5 & 49.5 & 25.6 & 0 & 15.6 & 0 & 0 & 18.2 & 0 \\
\hline Th & 18.2 & 0 & 12.8 & 0 & 0 & 0 & 43.5 & 19.2 & 0 & 0 & 0 & 0 & 0 & 0 & 0 \\
\hline$C t$ & 56.9 & 63.9 & 48.7 & 40.7 & 14.4 & 40.1 & 35.2 & 28.2 & 15.0 & 11.9 & 0 & 0 & 0 & 0 & 0 \\
\hline$c$ & 65.2 & 50.4 & 0 & 0 & 0 & 15.9 & 16.5 & 0 & 0 & 0 & 0 & 0 & 0 & 0 & 0 \\
\hline $\bar{T}$ & 33.2 & 24.11 & 0 & 0 & 0 & 20.11 & 16.11 & 12.11 & 0 & 0 & 14.11 & 9.22 & 0 & 0 & 0 \\
\hline
\end{tabular}

Legands: RT-Room temperature, Af-Aspergillus fumigatus, An-Aspergillus niger, Afl-Aspergillus flavus, Ar-Aspergillus rapens, At-Aspergillus tamari, $\mathbf{M m}-$ Mucor mucedo, Mmi-Mucor miehei, Hi-Humicola insolens, Hl-Humicola lanuginosa, P-Pythium sp, , Rs-Rhizotonia solani, $\boldsymbol{R}$ Rhizoctonia sp, Mt- Myceliophthora thermophila, Ct-Cladospora thermophila, Pc-Penicillium cinnmoni, Pd-Penicillium duponti, PbPenicillium befeldianum, Aa-Alternaria alternata, Fo-Fusarium oxysporun, Tv-Trichoderma viride, Th-Trihoderma harzianum, $\boldsymbol{C}$-Cladosporum sp, G-Geotrichum candidum, Cha-Chaetomium Rm Rhizopus microcarps, T-Torula sp.,PDA-Potato Dextrose Agar, CZA-Czapek’s Dox Agar and MBR- Martins Rose Bengal.

and Aspergillus fumigatus was present nearly in all of the sources (40) Aspergillus sp., was associated with different composts has been reported $(41,42)$. Study was conducted on municipal waste with microbial colonies like bacteria, fungi and actinomycetes in large numbers and temperature plays an important role in their growth during composting (43).

\section{Conclusion}

From the present investigation, it is concluded that the thermophiles prefer to colonize organic substrates. However, colonization of these fungi varied with different substrates and temperature level. In all 25 species representing 19 genera were isolated. Thermo tolerant fungi of Aspergillus niger and $A$. flavus were constantly associated and found common. A positive correlation was observed between percentage of incidence and temperature gradient level.

\section{Authors' contribution}

All the authors contributed equally to the work presented in this paper.

\section{Acknowledgements}

Authors are thankful to Kasturi Agroteh Lab, Late Kasturbai Walchand College Sangali, Department of Biotechnology for the biochemical analyses of composts.

\section{Competing Interests}

The authors declared that they have no conflict of interest.

\section{References}

1. Dix NJ, Webster J. Fungal Ecology. Chapman \& Hall, London, 1995; p. 549

2. Naik PS. Studies on microbial consortia for production and Enrichment of bio-compost from grapevine residues. Master of Science (Agriculture) Thesis submitted to the Department of Agricultural Microbiology College of Agriculture, Dharwad University of Agricultural Sciences, Dharwad 580 005. 2017

3. Asghar HN, Ishaq M, Zahir ZA, Khalid M, Arshad M. Response of radish to integrated use of nitrogen fertilizer and recycled

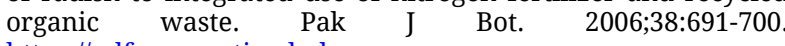
https://pdfs.semanticscholar.org 
4. Singleton P, Sambury D. Dictionary of Microorganisms. $4^{\text {th }}$ ed., John Willey and Sons Press, New York; 1998; p.1017

5. Tilman D, Cassman KG, Matson, PA. Naylor R, Polasky S. Agricultural sustainability and intensive production practices. Nature. 2002;418:671-77. https://doi.org/10.1038/nature01014

6. Goyal S, Dhull SK, Kapoor KK. Chemical and biological changes during composting of different organic wastes and assessment of compost maturity. Bioresour Technol. 2005;96,1584-91. https://doi.org/10.1016/j.biortech.2004.12.012

7. Zmora-Nahum S, O Markovitch, J Tarchitzky, Chen Y. Dissolved organic carbon (DOC) as a parameter of compost maturity. Soil $\begin{array}{lll}\text { Biol } & \text { Biochem. 2005;37:2109-16. }\end{array}$ https://doi.org/10.1016/j.soilbio.2005.03.013

8. Hernandez T, G Masciandaro JI, Moreno, Garcia C. Changes in organic matter composition during composting of two digested sewage sludges. Waste Manage. 2006;26:1370-76. https://doi.org/10.1016/j.wasman.2005.10.006

9. Anastasi A, GC, Varese, Marchisio VF. Isolation and identification of fungal communities in compost and

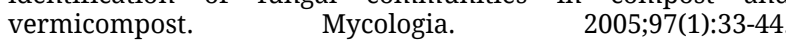
https://doi.org/10.1080/15572536.2006.11832836

10. Trautmann N. The Science and Engineering of Composting, Cornell Composting. Cornell University Press, Ithaca, New York, 1992

11. Subbiah BV, Asija GL. A rapid procedure for determination of available nitrogen in soils. Curr Sci. 1956;259-60

12. Sahilemedhin S, Bekele T. Procedures for soil and plant analysis. National soil research center Ethiopian Agricultural Research Organization. Addis Ababa, Ethiopia; 2000

13. Olsen SR, CV Cole, FS Watanabe, Dean LA. Estimation of available phosphorus in soils by extraction with sodium bicarbonate. USDA Circular No. 939. 1954

14. Bray RH, Kurtz LT. Determination of total, organic and available forms of phosphorus in soils. Soil Sci. 1945;59:30-45

15. Milner BA, Whiteside PJ. Introduction to Atomic Absorption Spectrophotometry. $3^{\text {rd }}$ Ed. Pye Unicam Ltd, York Street, Cambridge, England. 1984; p. 52

16. Hanway JJ, Heidel H. Soil analysis methods as used in Iowa State College Soil Testing Laboratory. Iowa Agri. 1952;57:1-31

17. Apinis AE. Thermophilous fungi of coastal grasslands in soil organisms. Proceedings of the colloquium on soil fanna, soil microflora and their relationships by J Doeksen, J Van der Drift (eds). North Holland, Amsterdam. 1963; pp. 427-38

18. Waksman SA, Umbreit WW, Cordon TC. Thermophilic actinomycetes and fungi in soils and in composts. Soil Sci. 1939;47:37-62

19. Girisham S. Studies on mycotoxin producing fungi associated with pearl millet (Pennisetum americanum L.). Ph.D thesis. Kakatiya University, Warangal. 1986

20. Subramanian CV. Hypomycetes:an account of Indian species except cercosporae. Indian Council of Agricultural Research, New Delhi. 1971; p. 463

21. Barnett HL, Hunter BB. Illustrated Genera of Imperfecti fungi. Burgess Publishing Company, Minneeapolis, Minnesota. 1972; p. 95

22. Mukadam DS. The Illustrated kingdom of fungi. Akshar Ganga Prakashan, Aurangabad. 1997; pp. 66-91

23. Kumar RR, Sreelatha B, Girisham S, Reddy SM. Incidence of thermophilic fungi from different substrates in Andhra Pradesh (India). International Journal of Pharma and Bio sciences. 2010;1(3):BS33. http://www.ijpbs.net/issue-3/34.pdf

24. Salar RK, Aneja KR. Thermophilic Fungi: Taxonomy and Biogeography. Journal of Agricultural Technology. 2007; 3(1):77-107

25. Sikora LJ, Szmidt RAK. Nitrogen sources, mineralization rates, and nitrogen nutrition benefits to plants from composts. In:
Compost utilization in horticultural cropping systems. Ed. PJ Stoffella, BA Kahn. Boca Raton: Lewis Publishers. 2001; pp. 287-320

26. Malinger FB Gotze, P Dreher, J Geszti, Weisstein C. Nitrogen in biowaste and yard waste compost: Dynamics of mobilisation and availability - A review. European Journal of Soil Biology, 2003;39:107-16

27. Yadav A, R Gupta, VK Garg. Organic manure production from cow dung and biogas plant slurry by vermicomposting under field conditions. International Journal of Recycling of Organic Waste in Agriculture. 2013;2,21. https://doi.org/10.1186/22517715-2-21

28. Benito M, A Massaguer, A Molinera, De Antonio R, De Antonio. Use of pruning waste compost as a component in soil less growing media. Bioresour. Technol. 2006; 97:2071-76

29. Rosen CJ, TR Halbach, Swanson BT. Horticultural uses of municipal solid waste components. Hortic. Technol. 1993;3:167-73

30. Batjes NH. Total carbon and nitrogen in the soils of the world. Eur. J. Soil Sci. https://doi.org/10.1111/ejss.12115

31. Blom BD, Emerson R. Studies on thermophily in fungi with particular reference to a new thermophilic Penicillium. Amer J Bot. 1962;49:665

32. Cooney DG. The thermophilic and thermotolerentmolds and Actinomycetes of mushroom compost during peak heating. Mycologia. 1964;56:267-84

33. Crisan EV, Fergus CL. Isolation and culture of thermophilic fungi. Boyce Thompson Inst. 1964;22:291

34. Cooney DG, Emerson R. Thermophilic fungi San. Francisco, W H Freeman, 1964; p.27

35. Ramesh $\mathrm{CH}$, Anil K. Studies on thermophilic fungi from different substrates of Dharwad, Karnataka. In: Proceeding of the National conference on Mycology plant pathology and Microbial Biotechnology, Department of Botany, Osmania University (Bagynarayana et al. Eds). Hyderabad. BS Publiations, Hyderabad. 2005; pp.96-103

36. Maheshwari R, Kamalam PT, Balasubrmanyam DV. The biogeography of thermophilic fungi. Curr Sci. 1987; 56:151-55

37. Cowan, MM. Plant products as antimicrobial agents. Clinical Microbiology Reviews, 1999;12 (4):564-82

38. Ashraf R, Faiza S, Tasneem AA. Association of fungi, bacteria and actinomycetes with different composts. Pak J Bot 2007;39(6):2141-51

39. Kurlekar SL. Effect of variable temperature on the growth of thermophilic fungi. Ad Plant Sci. 2014; 27(II):503-04

40. Bhale UN, VS Sawant, PP Sarwade, Rajkonda JN. Thermophilic fungi from different substrates of Osmanabad District. Bioinfolet. 2008;5(3):248-51

41. Wouters IM, S Spaan, J Douwes, G Doekes, Heederik D. Overview of personal occupational exposure levels to inhale dust, endotoxin, $\beta$ (1-3)-glucan and fungal extracellular polysaccharides in the waste management chain. Ann Occup Hyg. 2005;47:1-15. https://doi.org/10.1093/annhyg/mei047

42. Iranzo M, JV Canizares, L Roca-Perez, I Sainz-Pardo, S Mormeneo, Boluda R. Characteristic of rice straw and sewage sludge as composting materials in Valencia (Spain). Bioresource $\quad$ Technology. 2004;95(1):107-12. https://doi.org/10.1016/j.foodchem.2015.04.083

43. Pathak AK, MM Singh, V Kumar, S Arya, Trivedi AK. Assessment of physico chemical properties and microbial community during composting of municipal solid waste (viz KItchen waste) at Jhansi City, U. P. (India). Recent Research in Science and Technology. 2012;4(4):10-14 